Article

\title{
Variation in Response to Moisture Stress of Young Plants of Interspecific Hybrids between White Clover ( $T$. repens $L$.) and Caucasian Clover (T. ambiguum M. Bieb.)
}

\author{
Athole H. Marshall *, Matthew Lowe and Rosemary P. Collins \\ Institute of Biological, Environmental and Rural Sciences, Aberystwyth University, Gogerddan, \\ Aberystwyth, Ceredigion SY233EE, UK; E-Mails: mjl@aber.ac.uk (M.L.); rpc@aber.ac.uk (R.P.C.) \\ * Author to whom correspondence should be addressed; E-Mail: thm@aber.ac.uk; \\ Tel.: +44-197-082-3171; Fax: +44-197-082-8357.
}

Academic Editor: Cory Matthew

Received: 26 April 2015 / Accepted: 16 June 2015 / Published: 19 June 2015

\begin{abstract}
Backcross hybrids between the important forage legume white clover (Trifolium repens L.), which is stoloniferous, and the related rhizomatous species Caucasian clover (T. ambiguum M. Bieb), have been produced using white clover as the recurrent parent. The effect of drought on the parental species and two generations of backcrosses were studied in a short-term glasshouse experiment under three intensities of drought. Plants of Caucasian clover maintained a higher leaf relative water content and leaf water potential than white clover at comparable levels of drought, with the response of the backcrosses generally intermediate between the parents. Severe drought significantly reduced stolon growth rate and leaf development rate of white clover compared to the control, well-watered treatment, whilst differences between these two treatments in the backcross hybrids were relatively small. The differences between parental species and the backcrosses in root morphology were studied in $1 \mathrm{~m}$ long vertical pipes. The parental species differed in root weight distribution, with root weight of Caucasian clover significantly greater than white clover in the $0.1 \mathrm{~m}$ to $0.5 \mathrm{~m}$ root zone. The backcrosses exhibited root characteristics intermediate between the parents. The extent to which these differences influence the capacity to tolerate drought is discussed.
\end{abstract}

Keywords: white clover; interspecific hybrids; drought; leaf development rate; root weight distribution 


\section{Introduction}

Changing climatic conditions mean that the growing demand for meat and milk based products must be met against a backdrop of rising global temperatures and changing patterns of precipitation [1]. Extreme weather events, including periods of drought, will increasingly become a major factor limiting crop productivity in many parts of the world, including the UK [2]. Adaptation of agriculture to predicted climate change scenarios is essential, with the development of improved plant varieties better able to tolerate periods of drought [1] increasingly a key objective of many plant breeding programmes [3]. Selection criteria that will lead to new improved varieties of wheat [4,5] and grain legumes [6,7] better able to cope with drought are being developed. Grassland systems face similar challenges from climate change, therefore the development of new varieties of forage grasses and legumes better able to tolerate periods of drought is crucial.

The most important forage legume component of temperate pastures is white clover (Trifolium repens L.) [8], a nitrogen fixing species that produces forage of high quality. It is an outbreeding, highly heterozygous allotetraploid $(2 n=4 x=32)$ species and the wide genetic variation within its gene pool has been used successfully in the production of new varieties with improvements in many traits. Less variation has been identified for traits such as drought tolerance, which have proved difficult to improve significantly by conventional selection methods [9]. Although some authors [10] showed differences between ten white clover cultivars with respect to their response to drought, others [11] found little variation in response to a drought stress gradient between six lines (three cultivars and three germplasm accessions). Selection for deeper, more extensive root systems has been recommended for better tolerance to intermittent drought [12]. Selection for thicker roots as an indirect selection criterion has, however, been unsuccessful [13], although selection for increased root weight ratio (proportion of total plant DM allocated to roots) was found to improve the growth and survival of white clover in drought prone environments [14].

Introgression of genes from closely related species has been used successfully to introduce desirable traits into white clover [15-18] including improved drought tolerance [19]. Caucasian or Kura Clover (Trifolium ambiguum M. Bieb) is a strongly rhizomatous perennial legume species with good drought tolerance and persistence [20]. It is considered to have a wider range of adaptation than white clover [21], although slow seedling establishment tends to reduce its competitiveness with grasses in mixtures [22]. The extensive root and rhizome system is thought to act as a nutrient store that can be remobilised and used for growth, thus allowing this species to persist under stressful conditions [23]. Hybrids have been developed between white clover and Caucasian clover with the objective of introgressing the rhizomatous trait from Caucasian clover into white clover [16] as a strategy for improving drought tolerance whilst retaining the desirable agronomic traits associated with the latter species. Fertile backcrosss (BC) hybrids (derived from backcrossing to white clover) have been produced and these are essentially like white clover, but with rhizomes as well as stolons. A drought experiment comparing the $\mathrm{BC} 1$ and $\mathrm{BC} 2$ hybrids with the white clover and Caucasian clover parents in deep soil bins [16] showed that the backcross hybrids maintained lower values of leaf relative water content (RWC) and leaf water potential than Caucasian clover, but higher levels than white clover at comparable levels of drought. The mechanism by which Caucasian clover maintains a higher leaf RWC is not known, nor is the extent to which this mechanism operates within the hybrids. However, 
previous studies have shown that the hybrids allocate a higher proportion of their total DM yield to roots than white clover i.e., they maintain a higher root to shoot ratio [16]. Previous studies on white clover have shown that stolon growth and leaf development rate (LDR) are reduced by drought [24,25], but little is known about the effect of drought on these growth parameters in the backcross hybrids.

This study had the following objectives: firstly, to quantify the response of the backcross hybrids to drought; and secondly, to identify the extent to which ability to withstand drought may be related to differences in root depth distribution.

\section{Materials and Methods}

\subsection{Experiment 1}

\subsubsection{Plant Material and Experimental Treatments}

The T. ambiguum (Caucasian clover) accession Ah1254, collected in Turkey in 1971, and the T. repens (white clover) medium-leaved variety Menna were used in the hybridization programme. Fertile F1 plants were used as the basis for two generations of backcrossing to white clover as the recurrent parent. Details of the development of these backcrosses including methods of embryo rescue used in the development of the original hybrids and their morphological characterisation have been described previously $[8,16]$. Four genotypes within each of the white clover, Caucasian clover, BC1 and $\mathrm{BC} 2$ populations, selected based on their use in the development of the backcross populations, were cloned to provide six-plants of each genotype so that there were two clonal plants of each genotype available for each of three drought regimes. The genotypes of the $\mathrm{BC} 1$ and $\mathrm{BC} 2$ were selected on the basis of the presence of rhizomes and had been used in previous studies on forage yield and quality [16]. Clonal plants were obtained by removing a growing point with three nodes and planting in multi-compartment trays containing John Innes No. 3 compost. When they had produced at least three trifoliate leaves they were transplanted into $25 \mathrm{~cm}$ diameter $\times 27 \mathrm{~cm}$ deep pots filled with John Innes No. 3 compost. No rhizobia were added to the soil however nodules were observed on plant roots.

\subsubsection{Drought Tolerance}

There were three treatments: control (C) plants maintained at field capacity; moderate drought (M) plants maintained at $80 \%$ field capacity; severe drought (S) plants maintained at $65 \%$ field capacity. Field capacity was defined as the volume of water required for the soil within the pot to be saturated and was determined daily on the control plants. The $\mathrm{M}$ and $\mathrm{S}$ plants received $80 \%$ and $65 \%$ respectively of the quantity of water required by the $\mathrm{C}$ plants to maintain them at field capacity. This was repeated daily throughout the course of the experiment.

The experiment began when the plants were 3 months old, when they were cut to a height of $3 \mathrm{~cm}$ above ground level. At 21 and 35 days after the start of the experiment, pre-dawn leaf water potential was measured. Two leaflets were sampled per plant and leaf water potential measured using a pressure bomb (Portable plant moisture system SKPM 1400/40; Skye Instruments Ltd. Llandrindod Wells, UK) 
using the method described previously [25]. After 21 and 35 days, leaf relative water content (RWC) was determined on three leaves per plant as described [16] using the formula

$$
\mathrm{RWC}=((\mathrm{FW}-\mathrm{DW}) /(\mathrm{RW}-\mathrm{DW})) \times 100
$$

where FW = fresh weight, RW = rehydrated weight and DW = dry weight.

\subsubsection{Plant Growth}

Non-destructive measurements of stolon length and leaf development rate (LDR) were carried out on one rando mLy selected stolon per plant. At the beginning of the experiment the selected stolon was marked with an acrylic paint dot behind the youngest fully expanded leaf. After 7, 14, 21 and 28 days, stolon length from the tip of the growing point to the paint mark was measured and leaf development recorded using the criteria established by Carlson [26]: all leaves produced after the paint mark were given a score using the Carlson visual scale for leaf development, where 1.0 indicates a fully expanded leaf and 0.1 indicates a leaf just visible as it emerges. The sum of these scores was calculated for the measured stolon. The absence of stolons in Caucasian clover and the difficulty of measuring LDR in this species meant that this part of the experiment only compared white clover with the $\mathrm{BC} 1$ and $\mathrm{BC} 2$ hybrids. Thirty five days after the start of the experiment all plants were cut to a height of $3 \mathrm{~cm}$ above soil level. The leaf area of three leaves per plant was measured using a Delta-T-Devices leaf area meter and the dry weight of above ground material determined by drying for $12 \mathrm{~h}$ at $80{ }^{\circ} \mathrm{C}$ in a forced draught oven.

\subsection{Experiment 2}

\section{Root Depth Distribution}

Four clonal plants of each of the four genotypes of the populations used in Experiment 1 were obtained as described previously and planted into multi-compartment trays containing John Innes No. 3 compost. When they had produced three trifioliate leaves, they were transplanted into $1 \mathrm{~m}$ deep $\times 15 \mathrm{~cm}$ diameter plastic pipes with several drainage holes drilled in the base, into which was inserted a polythene tube filled with vermiculite. The pipes were placed vertically on a gravel bed in a glasshouse maintained at ambient temperature. The plants received $100 \mathrm{~mL}$ water daily and once a week received an additional $50 \mathrm{~mL}$ of a standard full-nutrient solution [27]. After ten weeks the polythene tube was removed from the pipe and the above ground foliage cut to ground level with hand held shears. The root column was removed and separated into $10 \mathrm{~cm}$ deep horizontal sections. The roots within each section were removed by washing under running water. The dry weight of the above ground biomass and root biomass within each section were determined after drying at $80{ }^{\circ} \mathrm{C}$ for $24 \mathrm{~h}$ in a forced draught oven.

\subsection{Data Analysis}

Experiment 1 was established as a split-plot design with two replicate blocks, comprising drought treatments as whole plots and genotypes as sub-plots. Growth parameters (leaf water potential, leaf relative water content, leaf development rate, stolon growth rate, dry matter yield and leaf size) were 
analysed by analysis of variance (ANOVA) using GenStat ${ }^{\circledR}$ (VSN International, Hemel Hempstead, UK) Release 13 [28] to determine significant effects of population, genotype within population and drought, and their interactions. Experiment 2 was established as a split-plot design with four replicate blocks, comprising populations as whole plots and genotypes as sub-plots. Root dry weight at each depth was analysed separately by ANOVA as above to determine significant effects of population and genotype within population.

\section{Results}

\subsection{Experiment 1}

\subsubsection{Overall analysis}

For most of the growth parameters measured there were significant effects of population and drought, and significant population $\times$ drought interactions, but no significant differences between genotypes within populations (Table 1). Consequently for all growth parameters only the population $\times$ drought means are presented.

Table 1. Significance levels for effect of drought, population and their interaction on plant growth parameters.

\begin{tabular}{ccccccccc}
\hline \multirow{2}{*}{ Treatment } & \multicolumn{2}{c}{ LWP } & \multicolumn{2}{c}{ Leaf RWC } & \multirow{2}{*}{ SGR } & \multirow{2}{*}{ LDR } & \multirow{2}{*}{ DM Yield } & \multirow{2}{*}{ Leaf Area } \\
& 21 Day & 35 Day & 21 Day & 35 Day & & $*$ & $*$ & $*$ \\
\hline Drought (D) & NS & $* * *$ & $* *$ & $*$ & $*$ & $*$ & $* *$ & $* * *$ \\
Population (P) & NS & $* * *$ & $* * *$ & $* * *$ & $* * *$ & $* * *$ & $* * *$ & $* * *$ \\
D $\times \mathrm{P}$ & $* * *$ & $* * *$ & $* * *$ & $* * *$ & NS & NS & $* * *$ & $* * *$ \\
\hline
\end{tabular}

NS, not significant; ${ }^{*} p<0.05 ; * * p<0.01 ; * * * p<0.001$; Key to abbreviations: LWP-leaf water potential, Leaf RWC-leaf relative water content, SGR-stolon growth rate, LDR-leaf development rate, DM yield - dry matter yield.

\subsubsection{Plant Water Status}

Results for the effects of the drought treatments and population on leaf water potential (LWP) are presented in Table 2. Twenty one days after the start of the experiment overall values of LWP were not affected by drought treatment, nor was there a difference between populations. However, there was a significant drought treatment $\times$ population interaction, such that LWP in white clover decreased more under the S drought treatment compared with LWP in Caucasian clover and the backcross hybrids. Thirty five days after the start of the experiment, drought treatment had a significant effect on overall values of LWP, which were greatly reduced under treatment S, followed by treatment $\mathrm{M}$, and both were less than under the well-watered control treatment $\mathrm{C}$. There was also a significant difference between populations and a significant drought $\times$ population interaction. As a result, LWP in white clover was significantly lower than in the other populations, and the magnitude of this reduction was greatest under the most severe drought treatment. Leaf RWC was significantly influenced by drought, population and there was a significant drought $\times$ population interaction when measured 21 and 35 days after the start of the experiment (Table 3). After 21 days, leaf RWC was lower under S than under M 
and $\mathrm{C}$ and in Caucasian clover was greater than that of white clover and the $\mathrm{BC} 1$ and $\mathrm{BC} 2$ hybrids. Leaf RWC of Caucasian clover was unaffected by moisture stress however in white clover and the $\mathrm{BC} 1$ and $\mathrm{BC} 2$ hybrids the leaf RWC was significantly lower under S than M and C. A similar result was observed after 35 days with the leaf RWC of Caucasian clover unaffected by moisture stress but the leaf RWC of white clover and the $\mathrm{BC} 1$ and $\mathrm{BC} 2$ hybrids significantly reduced under $\mathrm{S}$ in comparison with $\mathrm{M}$ and $\mathrm{C}$.

Table 2. Leaf water potential (MPa) of Caucasian clover, white clover, $\mathrm{BC} 1$ and $\mathrm{BC} 2$ hybrids after 21 and 35 days at three levels of drought. C-control treatment, $\mathrm{M}$ - moderate moisture stress, $\mathrm{S}$ - -severe moisture stress.

\begin{tabular}{|c|c|c|c|c|c|c|}
\hline \multirow{3}{*}{ Population } & \multicolumn{6}{|c|}{ Days after Start of Drought } \\
\hline & \multicolumn{3}{|c|}{21} & \multicolumn{3}{|c|}{35} \\
\hline & $\mathbf{C}$ & $\mathbf{M}$ & $\mathbf{S}$ & $\mathbf{C}$ & $\mathbf{M}$ & $\mathbf{S}$ \\
\hline Caucasian Clover & -0.47 & -0.58 & -0.76 & -0.50 & -0.73 & -0.76 \\
\hline White Clover & -0.27 & -0.51 & -1.35 & -0.39 & -0.85 & -2.00 \\
\hline $\mathrm{BC} 1$ & -0.32 & -0.57 & -0.80 & -0.30 & -0.69 & -1.69 \\
\hline $\mathrm{BC} 2$ & -0.26 & -0.41 & -0.94 & -0.32 & -0.62 & -1.49 \\
\hline \multicolumn{7}{|l|}{ S.e.d. } \\
\hline Drought (D) & \multicolumn{3}{|c|}{$0.270 \mathrm{NS}$} & \multicolumn{3}{|c|}{$0.037 * * *$} \\
\hline Population (P) & \multicolumn{3}{|c|}{$0.072 \mathrm{NS}$} & \multicolumn{3}{|c|}{$0.059 * * *$} \\
\hline $\mathrm{D} \times \mathrm{P}$ & \multicolumn{3}{|c|}{$0.291 * * *(0.124 * * *)$} & \multicolumn{3}{|c|}{$0.092 * * *(0.097 * * *)$} \\
\hline
\end{tabular}

NS not significant; ${ }^{* * *} p<0.001$; S.e.d in brackets to be used when comparing means with same level of drought.

Table 3. Leaf relative water content (\%) of Caucasian clover, white clover, $\mathrm{BC} 1$ and $\mathrm{BC} 2$ hybrids after 21 and 35 days at three levels of drought. $\mathrm{C}$-control treatment, $\mathrm{M}$-moderate moisture stress, $\mathrm{S}$ - -severe moisture stress.

\begin{tabular}{|c|c|c|c|c|c|c|}
\hline \multirow{3}{*}{ Population } & \multicolumn{6}{|c|}{ Days after Start of Drought } \\
\hline & \multicolumn{3}{|c|}{21} & \multicolumn{3}{|c|}{35} \\
\hline & $\mathbf{C}$ & $\mathbf{M}$ & $\mathbf{S}$ & $\mathbf{C}$ & $\mathbf{M}$ & $\mathbf{S}$ \\
\hline Caucasian Clover & 93.1 & 94.3 & 93.1 & 92.2 & 92.9 & 92.0 \\
\hline White Clover & 91.2 & 90.9 & 69.3 & 91.6 & 92.9 & 71.3 \\
\hline $\mathrm{BC} 1$ & 94.1 & 93.2 & 76.5 & 92.7 & 92.5 & 76.4 \\
\hline $\mathrm{BC} 2$ & 93.1 & 93.1 & 69.9 & 92.3 & 93.1 & 68.4 \\
\hline \multicolumn{7}{|l|}{ S.e.d. } \\
\hline Drought (D) & \multicolumn{3}{|c|}{$1.23 * *$} & \multicolumn{3}{|c|}{$1.96 *$} \\
\hline Population $(\mathrm{P})$ & \multicolumn{3}{|c|}{$1.61 * * *$} & \multicolumn{3}{|c|}{$1.63 * * *$} \\
\hline $\mathrm{D} \times \mathrm{P}$ & \multicolumn{3}{|c|}{$2.72 * * *(2.79 * * *)$} & \multicolumn{3}{|c|}{$3.13 * * *(2.82 * * *)$} \\
\hline
\end{tabular}

S.e.d. in brackets to be used when comparing means with same level of drought. $* p<0.05 ; * * p<0.01$; $* * * p<0.001$.

\subsubsection{Plant Growth}

Stolon growth rate (SGR) and leaf development rate (LDR) were influenced by drought and population but there was no significant interaction (Table 4). Drought reduced SGR, and generally the 
SGR of white clover was significantly higher than the $\mathrm{BC} 2$ and both were higher than in the $\mathrm{BC} 1$. The LDR of white clover was significantly greater than the backcross hybrids which were not significantly different from each other. Drought treatment reduced LDR but only under S; under M and $\mathrm{C}$ it did not differ significantly. Leaf area was significantly influenced by drought, differed between populations and there was a significant drought $\times$ population interaction. Generally leaf area was reduced by drought and the leaf area of white clover was greater than the $\mathrm{BC} 1$ and $\mathrm{BC} 2$ hybrids with the leaf area of Caucasian clover smallest. Leaf area of white clover and Caucasian clover was reduced by the $\mathrm{M}$ treatment and the leaf area of white clover further significantly reduced under the $\mathrm{S}$ treatment, unlike Caucasian clover which showed no further reduction in leaf area. The BC1 and BC2 hybrids exhibited a similar response to the $\mathrm{S}$ treatment as white clover.

Table 4. Stolon growth rate ( $\mathrm{mm} / 7$ days), leaf development rate (quantified using Carlson Scale) and leaf area $\left(\mathrm{mm}^{2}\right)$ of Caucasian clover, white clover, $\mathrm{BC} 1$ and $\mathrm{BC} 2$ hybrids after 35 days at three levels of drought. $\mathrm{C}$ - control treatment, $\mathrm{M}-$ moderate moisture stress, $\mathrm{S}-$ severe moisture stress.

\begin{tabular}{|c|c|c|c|c|c|c|c|c|c|}
\hline \multirow{2}{*}{ Population } & \multicolumn{3}{|c|}{ Stolon Growth Rate } & \multicolumn{3}{|c|}{ Leaf Development Rate } & \multicolumn{3}{|c|}{ Leaf Area $\left(\mathrm{mm}^{2}\right)$} \\
\hline & $\mathbf{C}$ & $\mathbf{M}$ & $\mathbf{S}$ & $\mathbf{C}$ & $\mathbf{M}$ & $\mathbf{S}$ & $\mathbf{C}$ & $\mathbf{M}$ & $\mathbf{S}$ \\
\hline Caucasian Clover & - & - & - & - & - & - & 358.2 & 303.0 & 184.9 \\
\hline White Clover & 3.8 & 4.0 & 1.1 & 9.9 & 10.0 & 5.6 & 280.4 & 241.9 & 178.6 \\
\hline $\mathrm{BC} 1$ & 2.1 & 1.6 & 0.4 & 6.1 & 7.0 & 4.8 & 309.8 & 265.4 & 257.0 \\
\hline $\mathrm{BC} 2$ & 3.1 & 2.3 & 0.6 & 6.4 & 7.0 & 4.3 & 322.2 & 248.3 & 220.8 \\
\hline Drought (D) & \multicolumn{3}{|c|}{$0.39 *$} & \multicolumn{3}{|c|}{$0.38 *$} & \multicolumn{3}{|c|}{$10.90 *$} \\
\hline Population (P) & \multicolumn{3}{|c|}{$0.32 * * *$} & \multicolumn{3}{|c|}{$0.43 * * *$} & \multicolumn{3}{|c|}{$10.19 * * *$} \\
\hline $\mathrm{D} \times \mathrm{P}$ & \multicolumn{3}{|c|}{$0.65 \mathrm{NS}(0.55 \mathrm{NS})$} & \multicolumn{3}{|c|}{$0.73 \mathrm{NS}(0.75 \mathrm{NS})$} & \multicolumn{3}{|c|}{$18.77 * * *(17.64 * * *)$} \\
\hline
\end{tabular}

$\mathrm{NS}$, not significant; $* p<0.05 ; * * * p<0.001$; S.e.d. in brackets to be used when comparing means with same level of drought.

Overall DM yield per plant was greater under $\mathrm{C}$ than in $\mathrm{M}$ and both greater than under the $\mathrm{S}$ treatment (Table 5). DM yield of white clover was significantly greater than the $\mathrm{BC} 1$ and $\mathrm{BC} 2$ hybrids and all had DM yields significantly greater than Caucasian clover reflecting the slow establishment of this species. There was also a significant drought $\times$ population interaction as drought had no significant effect on the DM yield of Caucasian clover but the DM yield of white clover and the $\mathrm{BC} 1$ and $\mathrm{BC} 2$ hybrids was significantly reduced by drought stress but white clover was reduced by a greater amount than the hybrids.

\subsection{Experiment 2}

There was a significant difference between populations in root dry weight to depths of $0.5 \mathrm{~m}$ and significant differences between genotypes within populations (Table 6). However, at depths below $0.5 \mathrm{~m}$ differences between populations were small and insignificant and are not shown. Root dry weight of white clover and Caucasian clover in the 0 to $0.1 \mathrm{~m}$ root zone was comparable (Figure 1). However, in subsequent zones, up to a depth of $0.5 \mathrm{~m}$, the root dry weight of Caucasian clover was significantly greater than that of white clover (Figure 1). Apart from the 0 to $0.1 \mathrm{~m}$ root zone where the $\mathrm{BC} 2$ had the greatest root dry weight, the root dry weight of the $\mathrm{BC} 1$ and $\mathrm{BC} 2$ hybrids were not 
significantly different and were generally intermediate between the two parental species. Differences in root dry weight between genotypes of white clover, $\mathrm{BC} 1$ and $\mathrm{BC} 2$ hybrids were observed at depths of $0.1-0.4 \mathrm{~m}$ but no significant differences between genotypes of Caucasian clover were observed.

Table 5. Dry matter yield (g/plant) of Caucasian clover, white clover, $\mathrm{BC} 1$ and $\mathrm{BC} 2$ hybrids after 35 days at three levels of drought. $\mathrm{C}$ - control treatment, $\mathrm{M}$-moderate moisture stress, S-severe moisture stress.

\begin{tabular}{cccc}
\hline \multirow{2}{*}{ Population } & \multicolumn{3}{c}{ Moisture Level } \\
\cline { 2 - 4 } & C & M & S \\
\hline Caucasian Clover & 3.3 & 2.1 & 1.5 \\
White Clover & 30.8 & 20.2 & 4.4 \\
BC1 & 22.7 & 17.7 & 4.9 \\
BC2 & 26.9 & 16.1 & 4.4 \\
Drought (D) & \multicolumn{3}{c}{$0.98 * *$} \\
Population (P) & \multicolumn{3}{c}{$0.75 * * *$} \\
P $\times$ S & \multicolumn{3}{c}{$1.49 * *(1.30 * * *)$} \\
\hline
\end{tabular}

** $p<0.01 ; * * * p<0.001$; S.e.d. in brackets to be used when comparing means with same level of drought.

Table 6. Significance levels for effect of population and genotype within population on root dry weight at different depths.

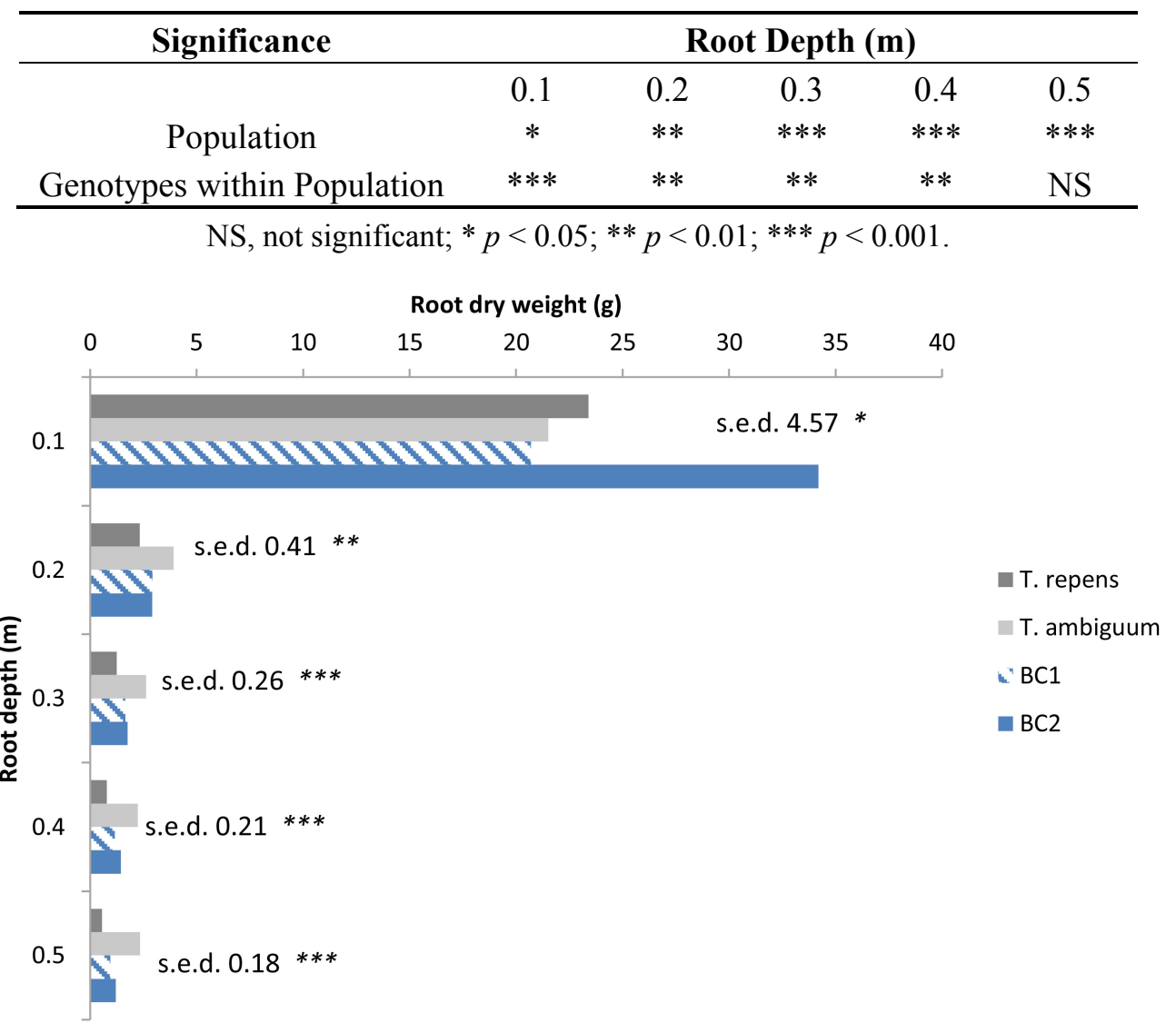

Figure 1. Root dry weight in $0.1 \mathrm{~m}$ sections of soil columns containing Caucasian clover, white clover, $\mathrm{BC} 1$ and $\mathrm{BC} 2$ hybrids. NS, not significant; * $p<0.05$; ** $p<0.01$; $* * * p<0.001$. 


\section{Discussion}

\subsection{Plant Water Status in Response to Drought}

It has been predicted that climate change will affect the distribution patterns of rainfall [29] and that this may have a negative impact on grassland productivity [30]. Development of forage varieties with a greater ability to tolerate drought is therefore an increasingly important target for forage plant breeding programmes [31]. Temperate pasture species such as white clover, whose agronomic yield consists of foliage, are considered to be more susceptible to drought stress than cereals or grain legumes [32]. One strategy to improve the drought tolerance of white clover is the development of interspecific hybrids between white clover and the drought tolerant, rhizomatous species Caucasian clover. Although the value of Caucasian clover as a drought tolerant species has been recognised in many Mediterranean areas, it has not been fully exploited due to its slow establishment [33].

Interspecific hybrids have been developed to introgress the rhizomatous trait into white clover without compromising the DM yield and forage quality of white clover [34,35]. Confirmation that Caucasian clover has a greater tolerance of drought than white clover has been clearly provided by the present experiment. Here, plants of Caucasian clover were found to maintain a higher leaf RWC and LWP than white clover under moderate and severe drought, confirming results from previous experiments carried out in deep soil bins [16]. Improved drought tolerance was also evident in the BC1 and BC2 hybrids, which maintained higher values of LWP and RWC than white clover, although lower than Caucasian clover. Consequently, after 35 days of the experiment, the plants of white clover were visibly wilting whilst those of the $\mathrm{BC} 1$ and $\mathrm{BC} 2$ hybrids were still turgid. In this experiment, plants were grown individually in large pots with limited opportunity for development of adventitious roots and rhizomes and were relatively juvenile plants when measured. Therefore care is necessary in extrapolating results directly to a field situation. Nevertheless, the results are comparable with previous experiments where genotypes of these populations were grown in deep soil bins and growth was typical of that observed in a previous a field plot experiment, in which adventitious roots were able to develop [16].

\subsection{Root Depth Distribution}

The objective of this experiment was to determine whether differences in response to drought in this germplasm might be associated with variation in root depth distribution. Plants tolerate drought through a range of mechanisms that include enhanced capture of soil moisture, limiting water loss and retention of cellular rehydration [36]. Rooting depth is one factor that influences soil moisture uptake. Drought resistant cultivars of species such as bean (Phaseolus vulgaris L.) [37] are those with thicker and deeper penetrating roots, and a higher proportion of total dry matter allocated to roots. In white clover, significant genetic variation has been observed for many root characters [38], some of which might be expected to confer improved drought tolerance. Some authors [39] for example, found significant genetic variation in seedling root system depth, and a high heritability for this character, within a collected population of white clover. These differences were related to dry matter yield under drought conditions, with genotypes from the "long" selection group producing higher yields than those with shorter roots. However, selection for thicker roots in white clover had varied success [13,14]. In 
the present experiment, Caucasian clover had a greater root weight than white clover at depths below $0.2 \mathrm{~m}$. The $\mathrm{BC} 1$ and $\mathrm{BC} 2$ hybrids also had a greater root weight than white clover at depths below $0.2 \mathrm{~m}$. This suggests that the introgression approach increased the allocation of resources to roots at lower depths thereby contributing to the improved drought tolerance of the hybrids compared to white clover.

When considering the effect of root system type on plant persistence in conditions of drought it is important to take into account both the timing of soil water deficits and the use of stored soil water in relation to crop phenology [40]. Thus, where soil water reserves exist at depth, the ability of plants to produce deep, extensive root systems is likely to be advantageous [41]. Conversely, where moisture reserves are confined to the upper layers of soil, then rooting depth becomes less important than the ability of plants to produce an efficient extraction system in these surface layers [41]. Although depth of rooting depends on soil type, cultivar and management, white clover is generally considered to be a shallow-rooted species, with most roots distributed in the top $0.1-0.2 \mathrm{~m}$ of soil [38]. This distribution pattern is likely to be detrimental to the ability of the species to persist under drought and suggests why the hybrids, with greater root weight than white clover below $0.2 \mathrm{~m}$, are more drought tolerant. In addition, there is evidence that the growth of white clover root systems per se is adversely affected by drought conditions. For example, the production of new roots of white clover has been found to be greatly reduced under drought stress [42,43]. Studies [44] comparing root system development in seedlings of three legume species, T. repens, Lotus corniculatus and Medicago lupulina, under different levels of drought found that the depth of penetration of the root system of white clover was considerably more reduced by drought than that of the other species. Consequently, in deep, moist soils the shallow root system of white clover was found to be adequate to sustain vegetative growth and seed production, but in conditions of drought an inability to penetrate the soil profile effectively was found not only to reduce dry matter yield but also to lead to lower seed production per plant and, ultimately, to plant mortality [44]. The effect of drought on the root growth of the BC hybrids was not included in the present study but could be the focus of future work, particularly including an analysis of root growth in different soil types.

\subsection{Plant Growth and Development}

Persistence and dry matter yield of white clover within mixed swards is determined by stolon growth and development and the rate at which leaves are produced at stolon nodes [45]. In white clover, stolon growth and leaf development rate have been shown to be reduced by drought stress [24,25] In one study [25], a moderate drought reduced leaf development rate by $40 \%$ and also reduced individual leaf area, effects that would have a considerable detrimental effect on DM yield if replicated in a mixed sward. A similar response to drought by white clover was observed in the present experiment, as severe drought significantly reduced stolon growth rate and production of new leaf area. Although the stolon growth, LDR and leaf area of the BC1 and BC2 hybrids were also reduced by severe drought the difference between growth in the well-watered control and the severe drought was, unlike white clover, relatively small. Both the moderate and severe drought treatment reduced the $\mathrm{DM}$ yield of white clover, $\mathrm{BC} 1$ and $\mathrm{BC} 2$ hybrids in comparison with the well-watered control. However, the greater drought tolerance in the hybrids was only reflected in a slight reduction in DM 
yield of the $\mathrm{BC} 1$ under moderate drought compared with white clover and the $\mathrm{BC} 2$. The reduction in $\mathrm{DM}$ yield of white clover, $\mathrm{BC} 1$ and $\mathrm{BC} 2$ hybrids was comparable under the severe drought treatment. Some similarity between white clover and the $\mathrm{BC} 2$ is not surprising since they are very closely related but it is possible that greater differences would have been observed had the experiment continued for longer than 35 days.

Although the $\mathrm{BC} 1$ and $\mathrm{BC} 2$ hybrids are essentially white clover-like in appearance, one of the surprising results was the lower stolon growth rate and of LDR both BC hybrids in the well-watered treatment compared with the white clover parent. No evidence of differences in stolon growth rate has been found during characterisation of this germplasm in spaced plant nurseries [8]. Further agronomic studies, carried out in field plots, have shown that the DM yield of the $\mathrm{BC} 1$ and $\mathrm{BC} 2$ hybrids when grown with L. perenne was slightly lower than in white clover in the first harvest year [34]. However, DM yield did improve in subsequent years and was comparable with white clover in the 2 nd and 3rd harvest years, suggesting that any differences in stolon growth may not be significant for long term pasture performance. Caucasian clover is a persistent species, but slow to establish with consequently low initial DM yields and grows poorly in pastures compared with white clover [21], largely due to its rhizomatous growth. The low stolon growth rate and DR may be a consequence of the introgression of the rhizomatous trait from Caucasian clover and further selection for improved stolon growth rate may be required.

\section{Conclusions}

Analysis of plant water status (leaf relative water content, leaf water potential) and plant growth and development in response to different levels of drought revealed significant variation between Caucasian clover and white clover, with an intermediate response of backcross hybrids between these two species. The parental species differed in root depth distribution and in root weight distribution, with root weight of Caucasian clover significantly greater than white clover in the $0.1 \mathrm{~m}$ to $0.5 \mathrm{~m}$ root zone with the backcross hybrids exhibiting root characteristics intermediate between the parental species. It is suggested that differences in root distribution is a factor influencing the extent to which plants are able to tolerate drought, however, further studies are required to quantify the impact of the differences in root distribution and rhizomes in mature plants.

\section{Acknowledgments}

This research was funded by the Department for the Environment, Food and Rural Affairs through the Sustainable Livestock LINK programme.

\section{Author Contributions}

Athole Marshall contributed to the experimental analysis and writing of the manuscript, aided by Rosemary Collins. Matthew Lowe was responsible for management of the experiments and data collection. 


\section{Conflicts of Interest}

The authors declare no conflict of interest.

\section{References}

1. Foresight. The Future of Food and Farming. Final Project Report; The Government Office for Science: London, UK, 2011.

2. Hopkins, A.; Del Prado, A. Implications of climate change for grassland in Europe: Impacts, adaptations and mitigation options: A review. Grass Forage Sci. 2007, 62, 118-126.

3. Abberton, M.T.; MacDuff, J.H.; Marshall, A.H.; Humphreys, M.W. The genetic improvement offorage grasses and legumes to enhance adaptation of grasslands to climate change. In Proceedings of the United National Climate Change Conference, Nusa Dua, Indonesia, 3-14 December 2007.

4. Foulkes, M.J.; Sylvester-Bradley, R.; Weightman, R.; Snape, J.W. Identifying physiological traitsassociated with improved drought resistance in winter wheat. Field Crops Res. 2007, 103, $11-14$.

5. Dodd, I.C.; Whalley, W.R.; Ober, E.S.; Parry, M.A.J. Genetic and management approaches to boost UK winter wheat yields by ameliorating water deficits. J. Exp. Bot. 2011, 62, 5241-5248.

6. Lizana, C.; Wentworth, M.; Martinez, J.P.; Villegas, D.; Meneses, R.; Murchie, E.H.; Pastenes, C.; Lercari, B.; Vernieri, P.; Horton, P.; et al. Differential adaptation of two varieties of common bean to abiotic stress. I. Effects of drought on yield and photosynthesis. J. Exp. Bot. 2006, 57, 685-697.

7. Martinez, J.P.; Silva, H.; Ledent, J.F.; Pinto, M. Effect of drought stress on the osmotic adjustment, cell wall elasticity and cell volume of six cultivars of common beans (Phaseolus vulgaris L.). Eur. J. Agron. 2007, 6, 30-38.

8. Abberton, M.T.; Michaelson-Yeates, T.P.T.; Marshall, A.H.; Holdbrook-Smith, K.; Rhodes, I. Morphological characteristics of hybrids between white clover, Trifolium. repens L. and Caucasian clover, Trifolium. ambiguum M. Bieb. Plant Breed. 1998, 117, 494-496.

9. Abberton, M.T.; Marshall, A.H. Progress in breeding perennial clovers for temperate agriculture. J. Agric. Sci. 2005, 143, 117-135.

10. Barbour, M.; Caradus, J.R.; Woodfield, D.R.; Silvester, W.B. Water stress and water use efficiency of ten white clover cultivars. In White Clover: New Zealand's Competitive Edge, Woodfield, D.R., Ed.; Grassland Research and Practice Series No. 6; New Zealand Grassland Association: Palmerston North, New Zealand, 1996; pp. 159-162.

11. Brink, G.E.; Pederson, G.A. White clover response to a water application gradient. Crop Sci. 1998, 38, 771-775.

12. Collins, R.P. The effect of drought stress and winter stress on the persistence of white clover. In Lowland Grasslands of Europe: Utilization and Development; Fisher, G., Frankow-Lindberg, B.E., Eds.; REUR Technical Series No. 64; FAO: Rome, Italy, 2002; pp. 17-32. 
13. Annicchiarico, P.; Piano, E. Indirect selection for root development of white clover and implications for drought tolerance. J. Agron. Crop Sci. 2004, 190, 28-34.

14. Caradus, J.R.; Woodfield, D.R. Genetic control of adaptive root characteristics in white clover. Plant Soil 1998, 200, 63-69.

15. Hussain, S.W.; Williams, W.M.; Mercer, C.F.; White, D.W.R. Transfer of clover cyst nematode resistance from Trifolium. nigrescens Viv. to T. repens by interspecific hybridisation. Theor. Appl. Genet. 1997, 95, 1274-1281.

16. Marshall, A.H.; Rascle, C.; Abberton, M.T.; Michaelson-Yeates, T.P.T.; Rhodes, I. Introgression as a route to improved drought tolerance in white clover (Trifolium. repens L.). J. Agron. Crop Sci. 2001, 187, 11-18.

17. Williams, W.M.; Hussain, S.W. Development of a breeding strategy for interspecific hybrids between Caucasian clover and white clover. NZ J. Agric. Res. 2008, 51, 115-126.

18. Williams, W.M. Trifolium interspecific hybridisation: Widening the white clover gene pool. Crop Pasture Sci. 2014, 65, 1091-1106.

19. Nichols, S.N., Hofman, R.W., Williams, W.M. Drought resistance of Trifolium repens $\times$ Trifolium uniflorum interspecific hybrids. Crop Pasture Sci. 2014, 65, 911-921.

20. Coolbear, P.; Hill, M.J.; Efendi, F. Relationships between vegetative and reproductive growth in a four year old stand of Caucasian clover (Trifolium. ambiguum M Bieb.) cv. Monaro. Proc. Agron. Soc. N. Z. 1994, 24, 77-82.

21. Taylor, N.L.; Smith, R.R. Kura clover (Trifolium. ambiguum M.B.) breeding, culture and utilization. Adv. Agron. 1998, 63, 153-178.

22. Black, A.D.; Moot, D.J.; Lucas, R.J. Development and growth characteristics of Caucasian and white clover seedlings, compared with perennial ryegrass. Grass Forage Sci. 2006, 61, 442-453.

23. Fu, S.M.; Hill, M.J.; Hampton, J.G. Root system development in Caucasian clover cv. Monaro and its contribution to seed yield. N. Z. J. Agric. Res. 2001, 44, 23-29.

24. Turner, L.B. The effect of water stress on the vegetative growth of white clover (T. repens L.): comparison of long-term water deficit and a short-term developing drought. J. Exp. Bot. 1991, 42, 311-316.

25. Belaygue, C.; Wery, J.; Cowan, A.A.; Tardieu, F. Contribution of leaf expansion, rate of leaf appearance and stolon branching to growth of plant leaf area under water deficit in white clover. Crop Sci. 1996, 36, 1240-1246.

26. Carlson, G.E. Growth of clover leaves developmental morphology at ten stages. Crop Sci. 1996, 6, 293-294.

27. Hoagland, D.R.; Snyder, W.C. Nutrition of strawberry under controlled conditions: (a) Effects of deficiencies of boron and certain other elements: (b) Susceptibility to injury from sodium salts. Proc. Am. Soc. Hortic. Sci. 1933, 30, 288-296.

28. Payne, R.W.; Murray, D.A.; Harding, S.A.; Baird, D.B.; Soutar, D.M. Introduction to GenStat ${ }^{\circledR}$ for Windows ${ }^{T M}$; VSN International: Hemel Hempstead, UK, 2010.

29. Humphreys, M.W.; Yadav, R.S.; Cairns, A.J.; Turner, L.B.; Humphreys, J.; Skøt, L. A changing climate for grassland research. New Phytol. 2006, 169, 9-26.

30. Humphreys, M.O. Grass roots for improved soil structure and hydrology. IBERS Knowl.-Based Innov. 2011, 2011, 21-25. 
31. Humphreys, M.O. Genetic improvement of forage crops-Past, present and future. J. Agric. Sci. 2005, 143, 441-448.

32. Turner, N.C.; Begg, J.E. Responses of pasture plants to water deficits. In Plant Relations in Pastures; Wilson, J.R., Ed.; CSIRO: Melbourne, Australia, 1978; pp. 50-66.

33. Widdup, K.H.; Knight, T.L.; Waters, C.J. Genetic variation for rate of establishment in Caucasian clover. Proc. Agron. Soc. N. Z. 1998, 60, 213-217.

34. Marshall, A.H.; Williams, T.A.; Abberton, M.T.; Michaelson-Yeates, T.P.T.; Powell, H.G. Dry matter production of white clover (Trifolium. repens L.), Caucasian clover (T. ambiguum M. Bieb) and their associated hybrids when grown with a grass companion over three harvest years. Grass Forage Sci. 2003, 59, 91-99.

35. Marshall, A.H.; Williams, T.A.; Abberton, M.T.; Michaelson-Yeates, T.P.T.; Olyott, P.; Powell, H.G. Forage quality of white clover (Trifolium. repens L.) $\times$ Caucasian clover $(T$. ambiguum M. Bieb) hybrids when grown with a grass companion over three harvest years. Grass Forage Sci. 2004, 59, 91-99.

36. Blum, A. Drought resistance, water-use efficiency, and yield potential-Are they compatible, dissonant or mutually exclusive? Aust. J. Agric. Res. 2005, 56, 1159-1168.

37. Sponchiado, B.N.; White, J.W.; Castillo, J.A.; Jones, P.G. Root growth of four common bean cultivars in relation to drought tolerance in environments with contrasting soil types. Exp. Agric. 1989, 25, 249-257.

38. Caradus J.R. The structure and function of white clover root systems. Adv. Agron. 1990, 43, 1-46.

39. Ennos, R.A. The significance of genetic variation for root growth within a natural population of white clover (Trifolium. repens L.). J. Ecol. 1985, 73, 615-624.

40. Clarke, J.M.; McCaig, T.N. Breeding for efficient root systems. In Plant breeding-Principles and Prospectsi; Hayward, M.D., Bosemark, N.O., Romagosa, I., Eds.; Chapman \& Hal: London, UK, 1993; pp. 485-499.

41. Wilson, D. Breeding for morphological and physiological traits. In Plant Breeding II; Frey, K.J, Ed.; Iowa State University Press: Ames, IA, USA, 1981; pp. 233-290.

42. Thomas, H. Effects of drought on growth and competitive ability of perennial ryegrass and white clover. J. Appl. Ecol. 1984, 21, 591-602.

43. Stevenson, C.A.; Laidlaw, A.S. The effect of moisture stress on stolon and adventitious root development in white clover (Trifolium. repens L.). Plant Soil 1985, 85, 249-257.

44. Fouldes, W. Response to soil moisture supply in three leguminous species. I. Growth, reproduction and mortality. New Phytol. 1978, 80, 535-545.

45. Elgersma, A.; Fengrui, L. Effects of cultivar and cutting frequency on dynamics of stolon growth and leaf appearance rate in white clover grown in mixed swards. Grass Forage Sci. 1997, 3, $370-380$.

(C) 2015 by the authors; licensee MDPI, Basel, Switzerland. This article is an open access article distributed under the terms and conditions of the Creative Commons Attribution license (http://creativecommons.org/licenses/by/4.0/). 